\title{
Review on Analytical Methods for Estimation of Itraconazole in Bulk and Pharmaceutical Dosage Form
}

\author{
Shweta Singh ${ }^{1}$, Anju Bhandole ${ }^{2}$, Devendra Lodhi ${ }^{3}$ \\ ${ }^{1}$ NRI Institute of Pharmacy, Bhopal \\ ${ }^{2}$ Shivan Pharmaceutical Studies and Research Center, Valasan, Gujarat \\ ${ }^{3}$ Sagar Group of Institution, Bhopal \\ Corresponding Author: Shweta Singh
}

\begin{abstract}
Itraconazole is an orally administered, trizole antifungal agent used in the treatment of systemic and superficial fungal infections. This includes infection in any part of body including the lungs, mouth or throat, toenails or fingernails. Some brands of itraconazole are not for use in treating fungal infections of the fingernails or toenails. Itraconazole has antimycotic properties. Formulated for both topical and systemic use.The objective of this review is to present summary and compilation of various research papers, which were already published in different national and international literature platform for estimation of itraconazole in bulk and pharmaceutical formulations with special emphasis on UV spectrophotometric and high performance liquid chromatography (HPLC) methods. There are various parameters used with UV Spectrophotometric and HPLC method, but few significant parameters are $\lambda \max$, solvent for UV Spectrometric method and stationary phase, mobile phase, retention time, column in case of HPLC. This compilation review presents all the analytical methods which were already used for estimation of itraconazole with their important parameters, which will be beneficial for the researchers and add to the existing literature in this field.
\end{abstract}

Keywords: Itraconazole, HPLC, UV, Pharmaceutical formulations, Method development.

\section{INTRODUCTION}

Itraconazole (ITZ) is antifungal drug. It is a white to almost white powder, chemically4-[4-[4-[4-[[cis-2-(2,4dichlorophenyl)-2-(1H-1,2,4-triazol-1ylmethyl)- 1,3dioxolan-4-yl]methoxy] phenyl]piperazin-1-yl]phenyl]-2-[(1RS)1methylpropyl]-2,4-dihydro-3H-1,2,4 triazol-3- one]. with molecular formula $\mathrm{C}_{35} \mathrm{H}_{38} \mathrm{C}_{12} \mathrm{~N}_{8} \mathrm{O}$ molecular weight $706 \mathrm{~g} / \mathrm{mol}$ [1] and chemical structure is shown in Figure 1.[2] Because of its low toxicity profile, this agent can be used for long-term maintenance treatment of chronic fungal infections[3]. Itraconazole was patented in 1978 and approved for medical use in the united states in 1992[4]. It is one of world health organization's lists of essential medicines [5].

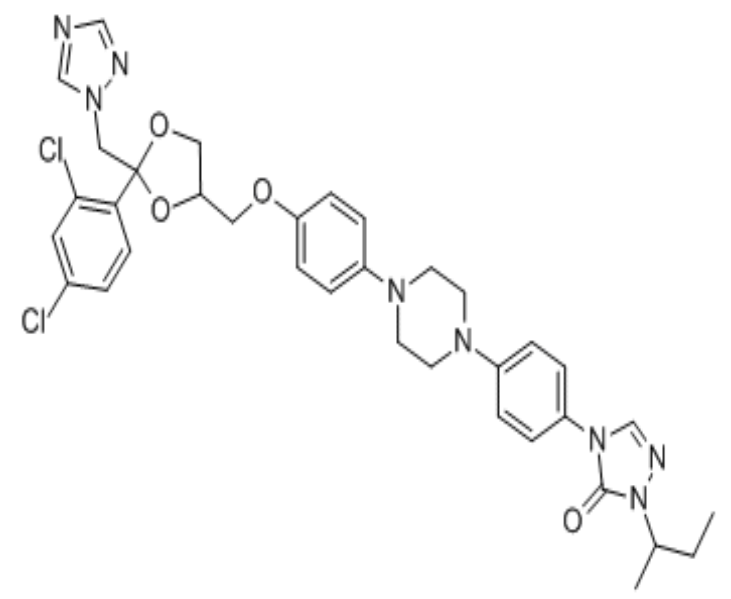

(Fig 1) 


\section{Mode of action}

The azole antifungal drugs act by inhibiting the synthesis of the sterol components of the fungal membrane. They inhibit C-14 alpha demethylase thereby blocking the demethylation of lanosterol to ergosterols the principal sterol of fungal membranes. This inhibition disrupts membrane structure and function which then inhibits fungal cell growth [6].

\section{Solubility}

It is soluble in organic solvents such as DMSO (dimethyl sulfoxide), DMF(dimethyl formamide). The solubility of itraconazole in these solvents is approx. $0.5 \mathrm{mg} / \mathrm{ml}$ and in $0.1 \mathrm{~N} \mathrm{HCL}$ is approx. 4-6 $\mu \mathrm{g} / \mathrm{ml}$ and in water $1-4 \mathrm{ng} / \mathrm{ml}$. Practically insoluble in water and dilute acidic solution [7].

Common side effect includes nausea, diarrhea, abdominal pain and headache, severe side effects may include linear problems, heart failure, stevens Johnson syndrome and allergic reaction [8]. Uses

Itraconazole had broader spectrum of activity than fluconazole. It is active against aspergillus.It is also licensed for use in blastomycosic, sporotrichosis, histoplasmosis and onchomycosis. It is over $99 \%$ protein bound and has virtually no penetration into cerebrospinal fluid. Therefore it should not be used to treat meningitis or other CNS injections [9]

\section{ANALYTICAL METHODS \\ UV-VISIBLE SPECTROPHOTOMETRIC METHODS}

UV spectrophotometric methods have been reported for the estimation of itraconazole in bulk and pharmaceutical formulations are shown in the Table 1.

Poonam et al. outlined UV Visible spectrometric method development and validation of itraconazole in bulk and capsule formulation. This method was carried out by using acidic ethanol as solvents and detection wavelength was at $262 \mathrm{~nm}$. The linearity was found to be in the range of $2-12 \mu \mathrm{g} / \mathrm{ml}$, Itaspor was marketed formulation used in the estimation. UV spectroscopy is based on the absorption law in which absorption of light by the molecules.

Rao et al. explained method development and validation of itraconazole by UV-Spectrophotometric in bulk and capsule dosage form. UV- spectroscopic determination was carried out at an absorption maximum of $267 \mathrm{~nm}$ using chloroform as solvents. The method was found linear in the concentration range of 1$10 \mu \mathrm{g} / \mathrm{ml}$ with correlation coefficient 0.999 . The method was validated by various parameter linearity, precision, accuracy, limit of detection, limit of quantitation.

Shalin et al. reported development of validation of UV - Spectrophometric method for estimation of itraconazole in bulk drug and pharmaceutical formulations. This method was performed on double beam UV-Visible Spectrophotometric having 2 matched quartz cells with $1 \mathrm{~cm}$ light path. Methanol was selected as ideal solvent for analysis of itraconazole and determination was carried out at an absorption maximum of $262 \mathrm{~nm}$. Accuracy of the method was confirmed by recovery study for marketed formulation at three level of standard addition. \% recovery of itraconazole was found to be 99.11-101.18 and the percentage of itraconazole in marketed formulation (Itaspor capsule) was calculated from the calibration curve of itraconazole. Percentage assay was found to be $100.44 \%$.

Sowjanya et al. examined UV Spectrophotometric method development and validation for determination of an antifungal agents in bulk and capsule.A sensitive zero order and (method A) and a first order derivative UV Spectrophotometric method was used for determination of itraconazole in formulation using phosphate buffer (PH 2.0). For (method A) the drug showed maximum absorbance at $255 \mathrm{~nm}$ and amplitude was measured in the range of $245 \mathrm{~nm}-270 \mathrm{~nm}$ (method B).Percentage recovery for itraconazole in the range of $98-101.66 \%$ 
indicates accuracy and \% RSD is less than 1.95 indicates precision of the methods.

Soumdarya et al. reported method development and analytical method validation of itraconazole by using UVSpectrophotometry. Itraconazole exhibited maximum absorption at $261 \mathrm{~nm}$ in the concentration range of $2.5-25 \mu \mathrm{g} / \mathrm{ml}$. The proposed method can be used as alternative method to the reported over for the routine detection of selected drug under the study in bulk and pharmaceutical dosage form. This method was stastically validated. The method was simple, sensitive and reliable with good precision and accuracy.

$$
\text { Murthy et al. studied }
$$

spectrophotometric estimation of itraconazole in pharmaceutical formulation. Two simple spectrophotometric methods (A and B) have been developed for determination of itraconazole in pure and in its pharmaceutical formulation .Method A is based on the formation of blood red colored complex with ferric chloride and absorption maximum at $320 \mathrm{~nm}$ where as in method B itraconazole forms a green colored complex with ferric chloride and 3-mthyl-2benzothiazoline hydrazine (MBTH) reagents exhibiting maximum absorption at $630 \mathrm{~nm}$. The chromogens obey beer's law in concentration ranges of 1.2 to $7.5 \mu \mathrm{g} / \mathrm{ml}$ and 2.5 to $20 \mu \mathrm{g} / \mathrm{ml}$ for method $\mathrm{A}$ and $\mathrm{B}$ respectively. The result obtained are reproducible and are stastically validated.

Tejaswina et al. analytical method development and validation of itraconazole by instrumental methods in bulk drug and marketed formulation. A zero order method was developed and validated on UV-Visible Spectrophotometric by using acetonitrile as solvents. The developed method was on zero order spectroscopy as per ICH guidelines and they are within the limits. The maximum absorption showed at $259 \mathrm{~nm}$.From solubility tests it was found that itraconazole is freely soluble in acetonitrile and showed good absorption. Assay was carried on the capsule formulation Itaspor 100mg.

Table 1: UV-visible spectrophotometric method for determination of Itraconazole

\begin{tabular}{|c|c|c|c|c|c|c|}
\hline S.no & Compound & Matrix & Method & Detection & Solvent & Reference \\
\hline 1 & Itraconazole & Capsule & UV spectrophotometric & $262 \mathrm{~nm}$ & Acetic ethanol & 10 \\
\hline 2 & Itraconazole & Capsule & Spectrophotometric & $267 \mathrm{~nm}$ & Chloroform & 11 \\
\hline 3 & Itraconazole & Capsule & Spectrophotometric & $262 \mathrm{~nm}$ & Methanol & 12 \\
\hline 4 & Itraconazole & Capsule & Spectrophotometric & $255 \mathrm{~nm}$ & Phosphate buffer (PH 2) Methanol & 13 \\
\hline 5 & Itraconazole & Capsule & Spectrophotometric & $261 \mathrm{~nm}$ & Methanol & 14 \\
\hline 6 & Itraconazole & Capsule & $\begin{array}{l}\text { Spectrophotometric } \\
\text { Method A } \\
\text { Method B }\end{array}$ & $\begin{array}{l}520 \mathrm{~nm} \\
630 \mathrm{~nm}\end{array}$ & $\begin{array}{l}\text { Ferric chloride }(0.033 \mathrm{M}) \\
1,10 \text { phenanthroline }(0.1 \mathrm{M}) \\
\text { Ferric chloride }(0.033 \mathrm{M}) \\
\text { 3-methyl-2-benzothiazoline hydrazine }\end{array}$ & 15 \\
\hline 7 & Itraconazole & Capsule & Spectrophotometric & $259 \mathrm{~nm}$ & Acetonitrile & 16 \\
\hline
\end{tabular}

\section{HIGH PERFORMANCE LIQUID CHROMATOGRAPHY (HPLC)}

In this review article we have tried to summarize the different chromatography conditions employed for establishing HPLC method and outcomes are given in the Table 2

Paruchuri et al. reported a new determination and validated RPHPLC method for the assay and related substance of itraconazole in capsule dosage form . The mobile phase consist of $0.08 \mathrm{M}$ terta butyl ammonium hydrogen sulphate: acetonitrile in the ratio of $65: 35$ with $1.5 \mathrm{ml} / \mathrm{min}$ flow rate in isocratic mode for separation of itraconazole. Thermohypersil BDS C18, 250 $\mathrm{mm} \times 4.66 \mathrm{~mm}, 5 \mu \mathrm{m}$ column for assay quantification was used with retention time $6.2 \mathrm{~min}$ and \% assay was found to be 99.9. The percentage recovery was found to be 99.6 to $101 \%$ after development of methods and it was validated according to International council on harmonisation (ICH) guidelines by various parameter linearity, precision, accuracy, specificity, robustness. The drug was subjected to forced degradation and stability studies.

Rao et al. studied development and validation of RPHPLC method for the determination of itraconazole in bulk and 
capsule dosage form. The optimized chromatographic conditions on HPLC system with enable $\mathrm{C} 18 \mathrm{G}$ column (250 $\mathrm{mm} \times 4.66 \mathrm{~mm}) 5 \mu \mathrm{m}$ particle size using mobile phase composed of acetonitrile and glacial acetic acid $0.1 \% \mathrm{w} / \mathrm{v}$ in ratio of 50:50 v/v. The separation was achieved using an isocratic elution mode with flow rate of $1 \mathrm{ml} / \mathrm{mim}$ at $264 \mathrm{~nm}$ using UV detector. The retention time (RT) of itraconazole was found to be $3.44 \mathrm{~min}$ and linear over a concentration range of 10-60 $\mu \mathrm{g} / \mathrm{ml}$ with $\mathrm{R}^{2}=0.996$. The proposed method was found to be specific, accurate, precise and robust. The advantage of new proposed method gives rapid results (retention time 3.44 mins) and quick analysis time (run time 5 mins.

Vujanovic et al. explained chemometrically assisted optimization and validation of RP-HPLC method for the analysis of itraconazole and its impurities in pharmaceutical dosage form. The mobile phase composition was acetonitrile/water PH 2.5 adjusted with ortho phosphoric acid (50: $50 \mathrm{v} / \mathrm{v})$. Separation were performed on a Zorbax Eelipse XDB-C18 $4.66 \mathrm{~mm} \times 150$ $\mathrm{mm}, 5 \mu \mathrm{m}$ particle size column and temperature of column set at $30^{\circ} \mathrm{C}$ with flow rate $1 \mathrm{ml} / \mathrm{min}$. The UV detector was used at $256 \mathrm{~nm}$ and the developed method was then subjected to method validation and the required validation parameters were tested. The validation parameters were found to be suitable the possibility to apply the proposed method for the determination of itraconazole and its impurities $\mathrm{B}$ and $\mathrm{F}$ in any laboratory under different circumstance has been proven.

Kumudhavali et al. reported a simple, specific, accurate and precise reverse phase HPLC method was developed and validated for the estimation of itraconazole in capsule dosage form. The mobile phase containing terbutyl ammonium hydrogen sulphate buffer solution and acetonitrile in the ratio of 40:60 $\mathrm{v} / \mathrm{v}$ at flow rate $1.5 \mathrm{ml} / \mathrm{min}$ and effluent were monitored at $225 \mathrm{~nm}$. An intersil $\mathrm{C} 18,5 \mu \mathrm{m}$ column having $250 \mathrm{~mm} \times 4.66 \mathrm{~mm}$ internal diameter in isocratic mode and retention time for itraconazole was $5.617 \mathrm{~min}$. The linearity shows in range of concentration $50-200 \mu \mathrm{g} / \mathrm{ml}$ with correlation coefficient 0.9993. The method was validated for linearity, precision, accuracy, limit of detection, limit of quantitation, specificity and robustness. The proposed method was successfully applied for the quantitative determination of itraconazole in capsule formulation.

Thangabalan et al. explained development and validation of RP HPLC method for the estimation of itraconazole in pure and pharmaceutical dosage form. The analysis was carried out using dionex C18 $4.66 \mathrm{~mm} \times 250 \mathrm{~mm}, 5 \mu \mathrm{m}$ enhanced polar selectivity column and mobile phase consist of methanol and $\mathrm{PH} 7.5$ potassium dihydrogen phosphate in the ratio of 40:60 and degassed under ultrasonification. The flow rate was $1.5 \mathrm{ml} / \mathrm{min}$ and effluents was monitored at $306 \mathrm{~nm}$. The retention time of itraconazole was found to be $5.2 \mathrm{mins}$ and linearity of itraconazole was in range of $200-600 \mu \mathrm{g} / \mathrm{ml}$. The $\%$ recoveries of itraconazole were $99.33 \%$ to $99.66 \%$ from the capsule formulation. The low detection and quantification limits achieved indicate the method is sensitive.

Yunoos et al. described determination of itraconazole in bulk and capsule dosage form by a validated isocratic RP-HPLC method. The chromatography was done on Zorbax C18 column $(150 \times$ $4.6 \mathrm{~mm}, 5 \mu \mathrm{m})$ and HPLC system was agilent 1100 series. The mobile phase consisting of acetonitrile and water in the ratio of 75:25 at flow rate of $1 \mathrm{ml} / \mathrm{min}$ and injection volume was $10 \mu \mathrm{l}$ with 7 min runtime. The detection was carried out using photo diode array (PDA) detector at $262 \mathrm{~nm}$. The proposed method was linear over a concentration range of $4-40 \mu \mathrm{g} / \mathrm{ml}$ for assay of itraconazole with correlation coefficient of 0.9993. The parameters of analysis were validated as per ICH guidelines. The LOD and LOQ were found to be $0.62 \mu \mathrm{g} / \mathrm{ml}$ respectively. The proposed method proven to be simple, selective and specific. 
Gupta et al. studied development and validation of RP-HPLC method for quantitation of itraconazole in tablet dosage form. The analysis was carried out using ODS Hypersil C18 column 250×4.6mm, $5 \mu \mathrm{m}$ with mobile phase consisting of a mixture of acetonitrile and $0.2 \%$ triethylamine in isocratic elution with $1 \mathrm{ml} / \mathrm{min}$ as flow rate. The detection was carried out by UV detector at $260 \mathrm{~nm}$. The retention time of itraconazole was about 4 min. This method permits determination of itraconazole in tablets with detection limit $0.3 \mathrm{ppm}$ and quantitation limit 1.0ppm. The linear regression analysis data for the calibration curve in the range of $1.0 \mathrm{ppm}$ to showed good linear relationship with coefficient correlation value $\mathrm{R}^{2}=0.9972$. All the parameters are validated by ICH guidelines.

Kasekar et al. reported development and validation of simple and rapid HPLC method for determination of itraconazole in bulk and marketed formulation. The mobile phase consist of acetonitrile and double distilled water in the ratio of $90: 10$ at flow rate of $1 \mathrm{ml} / \mathrm{min}$ and HiQ Sil C18 column with dimension $250 \times 4.6 \mathrm{~mm}$ for chromatographic separation. The detection was carried out with UV detector set as $263 \mathrm{~nm}$. The retention time for itraconazole was found to be $7.75 \mathrm{~min}$. The linearity range for itraconazole was found to be 5-60 $\mu \mathrm{g} / \mathrm{ml}$ with coefficient of linear regression 0.991 . Few reported mobile phase was binary that made use of phosphate buffer as one of component which can irreversibly damage the column therefore to extend column life along with column friendly acetonitrile, they tried ultrapure water instead of phosphate buffer, the solvents that has lowest density.

Mannem et al. described development and validation of RP-HPLC method for cis-bromo benzoate determination in itraconazole API (active pharmaceutical ingredient) and its pharmaceutical dosage form. The baseline separation for itraconazole and cis-bromo benzoate was achieved by utilizing a symmetry C18 $150 \times 4.6 \mathrm{~mm}, 3.5 \mu \mathrm{m}$ column particle size and an isocratic elution method. The mobile phase consist a mixture of acetonitrile in the ratio of 35:65 respectively with flow rate of $1 \mathrm{~min} / \mathrm{ml}$. The temperature of column was $25^{\circ} \mathrm{C}$ and detection was carried out $227 \mathrm{~nm}$. The LOD (limit of detection) for cis-bromo benzoate was $0.30 \mu \mathrm{g} / \mathrm{ml}$. The LOQ (limit of quantitation) for cis-bromo benzoate was $0.92 \mu \mathrm{g} / \mathrm{ml}$. The correlation coefficient obtained for impurity was less than 0.999 . The recovery was obtained for impurity was $100 \pm 10 \%$. The developed method was validated as per ICH guideline with respect to specificity, linearity, precision, accuracy, limit of detection, limit of quantitation, ruggedness, robustness and solution stability.

Wharton et al. reported rapid liquid chromatographic determination of itraconazole and its production impurities. The developed HPLC for determination of itraconazole were found to be linear, robust, accurate. Significant financial saving due to time and solvent reduction can be obtained by employed this method. This analysis time was reduced from the original time of 33 minutes to 10 minutes .The optimum chromatographic conditions were achieved using an agilent zorbax eclipse XDB C18 column, $1.8 \mu \mathrm{m}(4.6 \times 50 \mathrm{~mm})$ with mobile phase of $0.08 \mathrm{M}$ tetrabutyl ammoniun hydrogen sulphate buffer-acetonitrile (80:20 $\mathrm{v} / \mathrm{v}$ )with ultra violet detection at $235 \mathrm{~nm}$.

Tejaswini et al. studied analytical method development and validation of itraconazole by instrumental methods in bulk drug and marketed formulation. HPLC method was developed and validated for the determination of itraconazole in capsule formulation. The proposed method utilizes a

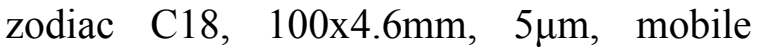
phase comprised of water and acetonitrile in the ratio of $50: 50 \mathrm{v} / \mathrm{v}$ and flow rate of 1.0 $\mathrm{ml} / \mathrm{min}$ with UV detection at $259 \mathrm{~nm}$. Result obtained with proposed method confirms the suitability of these methods for pharmaceutical dosage. The accuracy of the methods was confirmed by the recovery 
Shweta Singh et.al. Review on analytical methods for estimation of itraconazole in bulk and pharmaceutical dosage form

studies. The developed method can be used for determination of marketed formulations.

\begin{tabular}{|c|c|c|c|c|c|c|c|c|}
\hline $\begin{array}{l}\text { S. } \\
\text { No }\end{array}$ & Compound & Mobile phase & $\begin{array}{c}\begin{array}{c}\text { Stationary phase } \\
\text { (Column) }\end{array} \\
\end{array}$ & Detector & wavelength & $\begin{array}{c}\text { Retention } \\
\text { time }\end{array}$ & $\begin{array}{l}\text { Sample } \\
\text { Matrix }\end{array}$ & Reference \\
\hline 1 & Itraconazole & $\begin{array}{l}\text { Terta } \quad \text { butyl } \\
\text { ammonium hydrogen } \\
\text { sulphate : Acetonitrile } \\
65: 35\end{array}$ & $\begin{array}{l}\text { Thermohypersil BDS } \\
(150 \times 4.6 \mathrm{~mm}, 5 \mu \mathrm{m})\end{array}$ & UV & $225 \mathrm{~nm}$ & $6.2 \mathrm{~min}$ & Capsule & 17 \\
\hline 2 & Itraconazole & $\begin{array}{l}\text { Acetonitrile : Glacial } \\
\text { acetic acid } \\
50: 50\end{array}$ & $\begin{array}{l}\text { C18 column } \\
(250 \times 4.6 \mathrm{~mm}, 5 \mu \mathrm{m})\end{array}$ & UV & $264 \mathrm{~nm}$ & $3.44 \mathrm{~min}$ & Capsule & 18 \\
\hline 3 & Itraconazole & $\begin{array}{l}\text { Acetonitrile : water } \\
\text { (PH 2.5 adjusted with } \\
\text { o-phosphoric acid } \\
50: 50\end{array}$ & $\begin{array}{l}\text { zorbax eclipse XDB } \\
\text { C18 column, } \\
(4.6 \times 150 \mathrm{~mm} 5 \mu \mathrm{m})\end{array}$ & UV & $256 \mathrm{~nm}$ & & $\begin{array}{l}\text { Dosage } \\
\text { form }\end{array}$ & 19 \\
\hline 4 & Itraconazole & $\begin{array}{lr}\text { Terta } & \text { butyl } \\
\text { ammonium } & \text { hydrogen } \\
\text { sulphate } & \text { buffer } \\
\text { solution : Acetonitrile } \\
40: 60 & \\
\end{array}$ & $\begin{array}{l}\text { Intersil C18, } \\
250 \times 4.6 \mathrm{~mm}, 5 \mu \mathrm{m}\end{array}$ & UV & $225 \mathrm{~nm}$ & $5.6 \mathrm{~min}$ & Capsule & 20 \\
\hline 5 & Itraconazole & $\begin{array}{l}\text { Methanol and PH } 7.5 \\
\text { potassium dihydrogen } \\
\text { phosphate } \\
40: 60\end{array}$ & $\begin{array}{l}\text { Dionex C18 } \\
4.6 \mathrm{~mm} \times 250 \mathrm{~mm} 5 \mu \mathrm{m}\end{array}$ & UV & $306 \mathrm{~nm}$ & $5.2 \mathrm{~min}$ & Capsule & 21 \\
\hline 6 & Itraconazole & $\begin{array}{l}\text { Acetonitrile : water } \\
75: 25\end{array}$ & $\begin{array}{l}\text { Zorbax C18 } \\
(150 \mathrm{~mm} \times 4.6 \mathrm{~mm} \\
5 \mu \mathrm{m})\end{array}$ & $\begin{array}{l}\text { photo diode } \\
\text { array } \\
\text { (PDA) }\end{array}$ & $262 \mathrm{~nm}$ & $3.7 \mathrm{~min}$ & Capsule & 22 \\
\hline 7 & Itraconazole & $\begin{array}{l}\text { Acetonitrile : } 0.2 \% \\
\text { triethyl amine } \\
75: 25\end{array}$ & $\begin{array}{l}\text { ODS hypersil } \mathrm{C} 18 \\
\text { column }(250 \mathrm{~mm} \times 4.6 \\
\mathrm{mm}, 5 \mu \mathrm{m})\end{array}$ & UV & $260 \mathrm{~nm}$ & $4 \mathrm{~min}$ & Tablet & 23 \\
\hline 8 & Itraconazole & $\begin{array}{l}\text { Acetonitrile : Double } \\
\text { distilled water } \\
90: 10\end{array}$ & $\begin{array}{l}\text { HiQ Sil C18 } \\
(250 \mathrm{~mm} \times 4.66 \mathrm{~mm})\end{array}$ & $\overline{\mathrm{UV}}$ & $263 \mathrm{~nm}$ & $7.7 \mathrm{~min}$ & Capsule & 24 \\
\hline 9 & Itraconazole & $\begin{array}{l}0.1 \% \text { formic acid in } \\
\text { water : Acetonitrile } \\
35: 65\end{array}$ & $\begin{array}{l}\text { Symmetry C18 } \\
(100 \mathrm{~mm} \times 4.6 \mathrm{~mm}), \\
3.5 \mu \mathrm{m}\end{array}$ & $\begin{array}{l}\text { UV-Visible } \\
\text { PDA }\end{array}$ & $227 \mathrm{~nm}$ & $3.8 \mathrm{~min}$ & Tablet & 25 \\
\hline 10 & Itraconazole & $\begin{array}{lr}\text { Terta } & \text { butyl } \\
\text { ammonium } & \text { hydrogen } \\
\text { sulphate r buffer } \\
\text { solution : Acetonitrile } \\
80: 20 & \\
\end{array}$ & $\begin{array}{l}\text { agilent zorbax eclipse } \\
\text { XDB C18 column } \\
1.8 \mu \mathrm{m} \\
(4.66 \mathrm{~mm} \times 50 \mathrm{~mm})\end{array}$ & UV & $235 \mathrm{~nm}$ & & $\begin{array}{l}\text { Production } \\
\text { impurities }\end{array}$ & 26 \\
\hline 11 & Itraconazole & $\begin{array}{l}\text { Water : Acetonitrile } \\
50: 50\end{array}$ & $\begin{array}{l}\text { Zodiac } \\
\mathrm{mm} \times 4.66 \mathrm{~mm}, 5 \mu \mathrm{m})\end{array}$ & UV & $259 \mathrm{~nm}$ & $4.7 \mathrm{~min}$ & Capsule & 16 \\
\hline
\end{tabular}

\section{CONCLUSION}

There are various methods have been reported for the analysis of Itraconazole in bulk and pharmaceutical dosage form. The present review summarized all these method which are given on the literature specially emphasizing on UV spectrophotometric and high performance liquid chromatography (HPLC) methods for estimation of Itraconazole. The development of new methods will reduce the existing analytical problems includes improving resolution, decrease retention time and run time etc, which refined in terms of accuracy, precision, cost-effectiveness, more efficient and could be used for routine analysis. Liquid chromatography with UV detection has been found more effective assessment of
Itraconazole. The compilation of all methods for Itraconazole are shown in table no 1 and 2. This review covers UV spectrophotometric and HPLC methods for estimation of Itraconazole in bulk and pharmaceutical dosage form. Hence this review will help in further research and guide researchers for new method development on Itraconazole.

\section{Acknowledgement}

We sincerely thankful to our principal Mr Vivek Jain, NRI institute of pharmacy, Bhopal for providing facilities and helped us for conducting my work.

\section{Conflict of Interest: None}

\section{Source of Funding: None}




\section{REFERENCE}

1. Rao M, Trinadha., Ratna J, Vijaya., Rao Y, Srinivas., Development and validation of rphplc method for the determination of itraconazole in bulk and capsule dosage form. Internationl Journal of Pharmaceutical Sciences. 31(2), (2015) 221-225

2. Chemical book, CAS database list, itraconazole CAS No. 8465-61-6

3. National library of medicine (IN), itracozaole, pubchem 3793

4. Fischer,Jons., Ganellin C,Robin., Analogue based drug discovery. John wiley and sons .2006,503

5. World Health Organization. World health organization models lists of essential medicines, $21^{\text {st }}$ list 2019

6. Denyer, S.P., Hodges, N., Gorman, S.P., Gilmore, B.F., Hugo and russell's pharmaceuticals microbiology, A john wiley and sons Ltd .2011, $8,191-193$

7. O'Neil, M.J., The merck index - An encyclopedia of chemicals, Drugs and biological.Whitehouse station, NJ merck and Co.2006, 907

8. Itraconazole. The American society of health system pharmacists. Retrived on 8 december 2017.

9. Gilbert, D.N., Moellering, R.C., Eliopoulos, G.M., Sande,M.A., The Sanford guide to antimicrobial therapy.2006

10. Salunka A, Poonam., Ingale, Kamlesh., Gondhankheda, pooja., Ghate, Kanchan., Patil, S Shital., Visible spectrophotometry method development and validation of itraconazole in bulk and capsule formulation, analytical international journal in pharmaceutical analysis. 2017, 9(1), 45435-45439

11. Rao,M., Koteshware, R.K.V., Reshana S.R,Rao Narasimha D, Sujana.D.L, Method development and validation of itraconazole by UV-Spectrophotometer, World journal of pharmaceutical research. 2014,3(10), 777787

12. Parikh, K.S., Patel, D.Ankit., Dane, J .B., Patel, C.N., Sen, D.J., Development and validation of UV-Spectrophotometeric for estimation of itraconazole in bulk drug and pharmaceutical formulation, International journal of drug development and research . 2011,3(2),324-328

13. Sowjanya, Grummadi., Sindhuri, Varanasi., UV Spectrophotometeric method development and validation for determination of an antifungal in bulk capsule, Journal of pharmaceutical quality assurance quality control.2019,1(1), 11-17

14. Soundarya,G.,Rao, P., Venkateswara, Chandrika CH., Praveena, T., Method development and analytical method validation of itraconazole by using UVVisible spectrometry, Indo American journal of pharmaceutical sciences. 2018, 3 (5), $487-491$

15. Murthy, T.K., Reddy, M.N.,Yarraguntla, Srinivasa Rao., Sankar, .D.K., spectrophotometric estimation of itraconazole in pharmaceutical formulation, Indian journal of pharmaceutical sciences. $2002,491-493$

16. Tejaswani, E., Puranik, Sangamesh B., Development and validation of itraconazole by instrumental methods in bulk and marketed formulation, Universal journal of pharmacy. 2018, 7(4),7-20

17. Paruchuri, Sarvani., Pavanik, Haritha .,A new development and validated RP-HPLC method for the assay and related substance of itraconazole in capsule dosage form, Indian journal of research in pharmacy and biotechnology.2013,1(6),857-865

18. Rao,M.Trinadha., Ratna,J.Vijaya., Rao, Y. Shrinivas., Kumar,T.Hemant., Development and validation of RP-HPLC method for the determination of itraconazole in bulk and capsule dosage form, International journal of pharmaceutical sciences review and research. 2015, 31(2), 221-225

19. Vujanvoic, Kasagic.Irena., Maalenovic, Andelija., Jovanovic,Marko., Rakic, Tijana., Ivanovic, Darko., Chemometrically assisted optimization and validation of RP-HPLC method for the analysis of itraconazole and its impuritie, Acta pharma. 2013, 63,159173

20. Kumudhavali., Isocratic reverse phase HPLC,UV, method development and validation of itraconazole in capsule dosage form. International journal of pharmaceutical sciences research. 2011, 2 (12),3269-3271

21. Thangabalan ,B., Salomim, S.N., Monohar, Babu.S., Development and validation of RP HPLC method for the estimation of itraconazole in pure and pharmaceutical dosage form, Asian journal of pharmaceutical analysis.2013,3(4)

22. Yunoos Mohammad., Bharadwaj, Ch., Sandeep, V.,S, Rajesh.,Ch. Krishna., 

dosage form

Determination of itraconazole in bulk and capsule dosage form by a validated isocratic RP-HPLC method. Asian journal of research in chemistry. 2015, 8(4).

23. Gupta, M., Rajput, M., Development and validation of RP-HPLC method for quantitation of itraconazole in tablet dosage form, International journal of pharma research and review.2015

24. Kasekar, M.Nirmal., Godiyal, C.Shilpa., Jadhav, R.Kisan., Kadam, J.Vilassao., Development and validation of simple rapid HPLC method for the determination of itraconazole in bulk and marketed formulation. Der pharmacia letter, 2017 9(10), 36-43

25. Mannem, Babu., Durga, Kesana., Babu, Surendra., Development and validation of RP-HPLC method for cis-bromo benzoate determination in itraconazole API (active pharmaceutical ingredient) and its pharmaceutical dosage form. International journal of applied chemistry. 2017,4(3), 3440

26. Wharton, Mary, Geary, Michael., Sweetnan, Paul., Curtin, Laura., O' Connor, Niamh., Rapid liquid chromatographic determination of itraconazole and its production impurities. 2014, 52(3), 187-194

How to cite this article: Singh S, Bhandole A, Lodhi D. Review on analytical methods for estimation of itraconazole in bulk and pharmaceutical dosage form. International Journal of Research and Review. 2021; 8(5): 30-37. DOI: https://doi.org/10.52403/ijrr. 20210506 